\title{
ЗАНЯТОСТЬ ПОЖИЛОГО НАСЕЛЕНИЯ В УСЛОВИЯХ ЦИФРОВИЗАЦИИ ЭКОНОМИКИ
}

\author{
Антипанова O.A, \\ Барышева Г.А. \\ Национальный исследовательский \\ Томский политехнический университет, г. Томск, Россия
}

Демографический кризис и процесс старения населения неизбежно ведет $\kappa$ необходимости включения в сочиальную и трудовую деятельность лии пожилого возраста. Данная работа является актуальной на сегодняшний день в связи с повышением пенсионного возраста. Приведены сочиальные технологии, которые способны активизировать прочесс взаимодействия людей пожилого возраста с обществом и цифровыми технологиями.

Ключевые слова: цифровая экономика, мобильность, пожилые люди, умный город, качество жизни.

В 2018 году Президент выступил с ежегодным посланием Федеральному Собранию и призвал к масштабной цифровизации страны, в том числе, для создания «умных городов». Цифровая экономика - это новый этап развития общества и отразится на всех сферах жизнедеятельности российского гражданина.

Появление информационно-коммуникационные технологии значительно улучшает и облегчает жизнь, как в экономическом, так и социальном аспекте. Под цифровой экономикой понимают совокупность общественных отношений, услуг, инфраструктуры в рамках использования электронных технологий, а так же оптимизацию производственных процессов, которые ведут к повышению уровня социально-экономического развития государств в едином цифровом пространстве. На сегодняшний день функционируют множество цифровых платформ, обеспечивающих рынки товаров и услуг $[1,2]$.

С каждым годом процент пожилых людей увеличивается, что неизбежно ведет к необходимости их включения в социальную и трудовую деятельность. Повышение экономической, социальной активности возрастных людей и пенсионеров скажется на улучшении их качества жизни.

Актуальность данной работы обусловлена тем, что в условиях цифровой экономики меняется содержание и форма труда. И в связи с повышением трудового возраста необходимо возрастное население адаптировать к новым профессиональным компетенциям, которые ставят перед работниками работодатели. Ведь трудовая деятельность становится мобильной и совершенно независима от конкретной территории или рабочего места. Вполне возможно на этих специалистов появится спрос. Именно поэтому уже сейчас необходимы инициативы от общества или государства, способствующие подготовке 
возрастных специалистов с навыками работы с цифровыми данными и технологиями.

При достижении предпенсионного возраста, особенно это проявляется в развитых мегаполисах, реальное положение на рынке труда для большего числа пожилых работников, занимающихся поиском работы, ухудшается. В большинстве стран эта категория людей сталкивается с дискриминацией в отношении найма на работу, профессиональной переподготовки и повышения квалификации. При этом государство активно повышает пенсионный возраст, предприятия не берут на работу таких граждан.

Для преодоления этой негативной тенденции в ряде стран государства инвестируют средства в профессиональное обучение (пример: повышение уровня технологических навыков, чтобы граждане могли быстрее адаптироваться в инновационных условиях) и дополнительное профессиональное образование граждан предпенсионного возраста [2]. Такая специальная правительственная программа, призванная повысить конкурентоспособность на рынке труда предпенсионеров с учетом потребностей работодателей (предшествующий пенсии период увеличился до пяти лет (ст. 5 закона № 1032-1 от 19.04.1991 о занятости населения) реализуется в России.

В странах ЕС уже давно запущен процесс интенсивного развития новой модели труда и занятости пожилых людей в связи с цифровой экономикой. Например, в Тайване реализуется социальная программа, направленная на образование и переобучения с разнообразными учебными электронными курсами с целью внедрения активного обучения лиц старше 55 лет [4]. Также таким примером, может послужить наша отечественная программа в Томской области. В 2019 году переобучили 358 человек, им была предусмотрена субсидия не более 68500 рублей за обучение человека, срок обучения от 16 до 500 часов, но не более трех месяцев, стипендия в размере величины МРОТ (11 280 руб.), увеличенного на районный коэффициент [3].

Вопреки укоренившимся стереотипам научные исследования показывают, что пожилые работники в среднем так же эффективны в своей работе, как и молодые. Пожилые сотрудники имеют меньше несчастных случаев на рабочем месте, чем молодые, и реже покидают организацию добровольно. Без принятия мер по ликвидации дискриминации по возрасту активная политика, ориентированная на пожилых граждан, вероятно, будет иметь ограниченный успех. Принципы эффективной стратегии активного долголетия должны основываться на социальном партнерстве между гражданином и обществом. В этом партнерстве роль государства заключается в том, чтобы создавать условия, а так же облегчать и мотивировать граждан и, при необходимости, как можно дольше обеспечивать качественную социальную защиту незащищенным слоям населения. Что касается общества, то задача политики заключается в том, чтобы признать связь, которая связывает воедино все соответствующие области политики: занятость, здравоохранение, социальная защита, социальная интеграция, транспорт, образование [5]. 
Среди социальных технологий, способных активизировать процесс взаимодействия людей пожилого возраста с обществом и цифровыми технологиями, можно отметить следующее:

- специализированные программы работы со средствами массовой информации по формированию нового образа пожилого человека и демонстрации разнообразия жизненных позиций и способов самореализации в этом возрасте;

- социальная поддержка в решении проблем пожилых людей не только через государственные органы, но и посредством добровольческих объединений;

- внедрение в практику межпоколенных взаимодействий, расширяющих практику сотрудничества и общественного согласия путем расширения сети бесплатных курсов различного профиля (компьютерной грамотности);

- организация мониторинга спроса и предложения рабочей силы, который ориентирован на возрастную категорию граждан.

\section{Исследование выполнено при финансовой поддержке РФФИ в рамках научного проекта № 19-18-00300.}

\section{Список литературы}

1. Was die Industrie 4.0 den Beschäftigten bringt // Böckler Impuls. - 2015. Ausg. 4. - S. 4-5.

2. Hirsch-Kreinsen H. Welche Auswirkungen hat "Industrie 4.0" auf die Arbeitswelt? - Bonn: Friedrich-Ebert-Stiftung, Abteilung Wirtschafts- und Sozialpolitik, 2014. - 4 s. - (Wiso direkt). - URL: http://library.fes.de/pdffiles/wiso/11081.pdf.

3. Распоряжение Правительства № 3025-p от 30.12.2018 «Об утверждении специальной Программы профессионального обучения и дополнительного профессионального образования граждан предпенсионного возраста на период до 2024 года» [Электронный ресурc]. - URL: https:// rulaws.ru/goverment/Rasporyazhenie-Pravitelstva-RF-ot-30.12.2018-N-3025-r/

4. Li, A. and Wei, H. (2019), Lifelong Learning for Aging People in Taiwan: Innovative Programs and Social Effects. New Directions for Adultand Continuing Education, 2019: 97-110.

5. Келасьев Олег Вячеславович Провинциальная старость и ее новые интерпретации Рогозин Д. М. , Ипатова А. А. (ред.) (2016) Старикам тут место: социальное осмысление старения. М.: институт социологии РАН.// ЖИСП. 2018. №1. 264 c. 